\section{Eggplant (Solanum melongena L.) Plant Growth and Fruit Yield as Affected by Drip Irrigation Rate}

\author{
Juan Carlos Díaz-Pérez ${ }^{1}$ \\ Department of Horticulture, University of Georgia, Tifton, GA 31793
}

Touria E. Eaton

Cooperative Extension and Research, Lincoln University of Missouri, Jefferson City, MO 64106

Additional index words. Solanum melongena, irrigation, water use efficiency, nitrate, leaching water (above the rate of ETc) and $\mathrm{N}$ fertilizer, resulting in water waste and $\mathrm{N}$ leaching. Excessive irrigation rate not only wastes water, but may also result in reduced yields in bell pepper (Díaz-Pérez et al., 2004; Sezen et al., 2006) and tomato (Locascio et al., 1989; Ngouajio et al., 2007). To our knowledge, there are no published studies in the United States on the effect of irrigation rate on the yield and plant growth of drip-irrigated eggplants. Irrigation studies, intended to optimize use of irrigation water, are necessary to enable the protection of water resources in the United States. Therefore, the objective of this research was to assess the effects of irrigation rate on plant growth and fruit yield in eggplant.

\section{Materials and Methods}

Study site. The study was carried out at the Horticulture Farm, University of Georgia, Tifton, GA, during the fall of 2010 and 2011. The farm is located at an altitude of $108 \mathrm{~m}$ above mean sea level, $31^{\circ} 28^{\prime} \mathrm{N}$ latitude and $83^{\circ} 31^{\prime} \mathrm{W}$ longitude. The soil of the farm is a Tifton sandy loam (a fine loamy-siliceous, thermic Plinthic Kandiudults) with $\mathrm{pH}$ 6.5. Available water capacity is 18 to $36 \mathrm{~mm}$ in the top $30 \mathrm{~cm}$ of soil profile (Calhoun, 1983). In 2010, field had a gentle sloping (slope $\approx 3 \%$ ); in 2011 , field had a nearly level slope. The distance between the 2010 and 2011 fields was $\approx 70 \mathrm{~m}$.

Land preparation and planting. Eggplant plants were grown on plastic film mulch on raised beds $(6 \times 0.76 \mathrm{~m}$, formed on $1.8-\mathrm{m}$ centers). Before laying mulch, the soil was fertilized with $\mathrm{N}$, phosphorous $(\mathrm{P})$, and $\mathrm{K}$ at 60,26 , and $50 \mathrm{~kg} \cdot \mathrm{ha}^{-1}$, respectively, using 10-10-10 granular fertilizer. At the same time, plastic film mulch [white on black, low-density polyethylene with a slick surface texture, $1.52 \mathrm{~m}$ wide and $25 \mu \mathrm{m}$ thick (RepelGro, ReflecTek Foils, Inc., Lake Zurich, IL)] was laid with a mulch-laying machine, drip irrigation tape [20.3 $\mathrm{cm}$ emitter spacing and a $8.3 \mathrm{~mL} \cdot \mathrm{min}^{-1}$ emitter flow (Ro-Drip, Roberts Irrigation Products, Inc., San Marcos, CA)] was placed $5 \mathrm{~cm}$ deep in the center of the bed.

Eggplant transplants were produced in a greenhouse using peat-based medium (Pro-Mix, Quakertown, PA) and polystyrene 200 -cell $(2.5 \times 2.5 \mathrm{~cm}$ cell $)$ trays. Six-weekold eggplant transplants were planted with a mechanical transplanter on 6 Aug. 2010 and 5 Aug. 2011 in one row per bed, with a $60 \mathrm{~cm}$ separation between plants. About $250 \mathrm{~mL}$ of starter fertilizer solution $\left(555 \mathrm{mg} \cdot \mathrm{L}^{-1} \mathrm{~N}\right.$; $\left.821 \cdot \mathrm{mg} \cdot \mathrm{L}^{-1} \mathrm{P} ; 0 \mathrm{mg} \cdot \mathrm{L}^{-1} \mathrm{~K}\right)$ was applied directly to the base of each transplant. The length of the experimental plot was $6.1 \mathrm{~m}$. Starting 3 weeks after transplanting, plants were fertilized weekly through the drip system with $\mathrm{N}$ and $\mathrm{K}$. Fertilization rates of $\mathrm{N}$ and $\mathrm{K}$ after transplanting were $0.7,1.0$, 1.5 , and $2 \mathrm{~kg} \cdot \mathrm{ha}^{-1} \cdot \mathrm{d}^{-1}$ in week 5 , week 6 ; week 7 ; and weeks $13-15$, respectively. Total $\mathrm{N}-\mathrm{P}-\mathrm{K}$ applied in the season was $218 \mathrm{~kg} \cdot \mathrm{ha}^{-1}$ $\mathrm{N}, 30 \mathrm{~kg} \cdot \mathrm{ha}^{-1} \mathrm{P}$, and $181 \mathrm{~kg} \cdot \mathrm{ha}^{-1} \mathrm{~K}$. 
Experimental design and treatments. The design was a randomized complete block with five treatments and four replications. Treatments consisted of irrigation rates based on ETc $(33 \%, 67 \%, 100 \%, 133 \%$, and $167 \%$ the rate of ETc). ETc was calculated by multiplying the reference evapotranspiration (ETo) by a crop coefficient $(\mathrm{Kc})$, which is dependent on the crop stage of development. Available Kc values for eggplant were developed for bare soil (unmulched) production. These $\mathrm{Kc}$ values, however, are not recommended for crops under plasticulture systems since plastic mulches reduce soil evaporation and ETc (Allen et al., 1998; Pereira et al., 2015; Simonne et al., 2006). The Kc values used in this study were modified relative to those proposed for bell pepper in Florida (Simonne et al., 2006). The Kc values used were 0.25 (week 1 after transplanting), 0.40 (week 2), 0.55 (week 3), 0.70 (week 4), 0.85 (week 5), 1.0 (week 6-11), and 0.8 (week 12-14).

All treatments received equal volumes of irrigation water ( 88 and $49 \mathrm{~mm}$ in 2010 and 2011, respectively) during the crop establishment period (first 4 weeks after transplanting). Irrigation treatments were initiated on week 5 . Water was applied when cumulative ETc was $\approx 12 \mathrm{~mm}$, which corresponded to about every 2 to $3 \mathrm{~d}$ in mature plants (mean ETo was 5 to $6 \mathrm{~mm} \cdot \mathrm{d}^{-1}$ ). Thus, amounts of water per irrigation event were $\approx 4 \mathrm{~mm}(33 \%$ ETc), 8 mm (67\% ETc), 12 mm (100\% ETc), $16 \mathrm{~mm}(133 \% \mathrm{ETc})$, and $20 \mathrm{~mm}$ (167\% ETc).

Soil water content. Soil water content (volumetric) in the $0-12 \mathrm{~cm}$ of soil profile over the season was measured manually once every $2-3 d$ (three readings per experimental plot) with a portable time-domain reflectometry (TDR) sensor (CS-620; Campbell Scientific, Logan, UT). The two metallic $12-\mathrm{cm}$ rods of the TDR sensor were inserted vertically within the row between two plants. Soil water content (volumetric) in the $0-30 \mathrm{~cm}$ of soil profile was periodically (every $10 \mathrm{~min}$ ) monitored with TDR sensors (CS-610; Campbell Scientific) connected to a datalogger (CR-10X; Campbell Scientific). The moisture sensors had three metallic $30-\mathrm{cm}$ rods and were inserted vertically within the row between two plants.

Soil nitrate. Soil samples were taken from each plot at 0 - to $20-\mathrm{cm}, 20-$ to $40-\mathrm{cm}$, and 40- to 60-cm depths on 8 Nov. 2010. Samples were taken at least $0.5 \mathrm{~m}$ away from the borders of the plots and from the previous sampling holes. Samples were air-dried and analyzed for nitrate-nitrogen using standard QuickChem Methods (Lachat Quick-Chem 8000 FIA; Zellweger Analytics, Milwaukee, WI).

Plant growth. Eggplant plant height and stem diameter were measured weekly in three mature plants per plot. Plant samples obtained at the end of the season were dried at $70{ }^{\circ} \mathrm{C}$ for several days until constant weight was obtained. Leaf, stem, and vegetative top (leaf + stem) DW of individual plants were determined.

Leaf CI. Chlorophyll indices were determined twice a week over the season on six mature, well-exposed, and healthy leaves per plot using a chlorophyll meter (Chlorophyll Meter SPAD-502; Minolta Co., Ltd., Ramsey, NJ).

Leaf gas exchange and PSII efficiency. Simultaneous measurements of leaf gas exchange (net photosynthesis, $g_{\mathrm{S}}$, transpiration, and internal $\mathrm{CO}_{2}$ concentration), and fluorescence were determined as PSII efficiency were made with an infrared gas analyzer (LI-COR 6400 IRGA with an integrated 6400-40 leaf chamber fluorometer; LI-COR, Inc., Lincoln, NE). PSII efficiency is the fraction of absorbed PSII photons used in photochemistry and is measured with a lightadapted leaf. Water use efficiency (WUE) was calculated as the ratio between leaf net photosynthesis and leaf transpiration. Air flow rate was set at $300 \mu \mathrm{mol} \cdot \mathrm{m}^{-2} \cdot \mathrm{s}^{-1}$ on the reference side. The $\mathrm{CO}_{2}$ concentration was set at $400 \mu \mathrm{mol} \cdot \mathrm{mol}^{-1}$ with a $\mathrm{CO}_{2}$ mixer and a $\mathrm{CO}_{2}$ tank. Measurements were conducted in developed plants on clear days (photosynthetically active radiation $\approx 2000 \mu \mathrm{mol} \cdot \mathrm{m}^{-2} \cdot \mathrm{s}^{-1}$ ) at 1200-1500 HR Eastern Standard Time in 2010 (6 and 20 Oct. and 9 Nov.) and 2011 (5 Oct.),
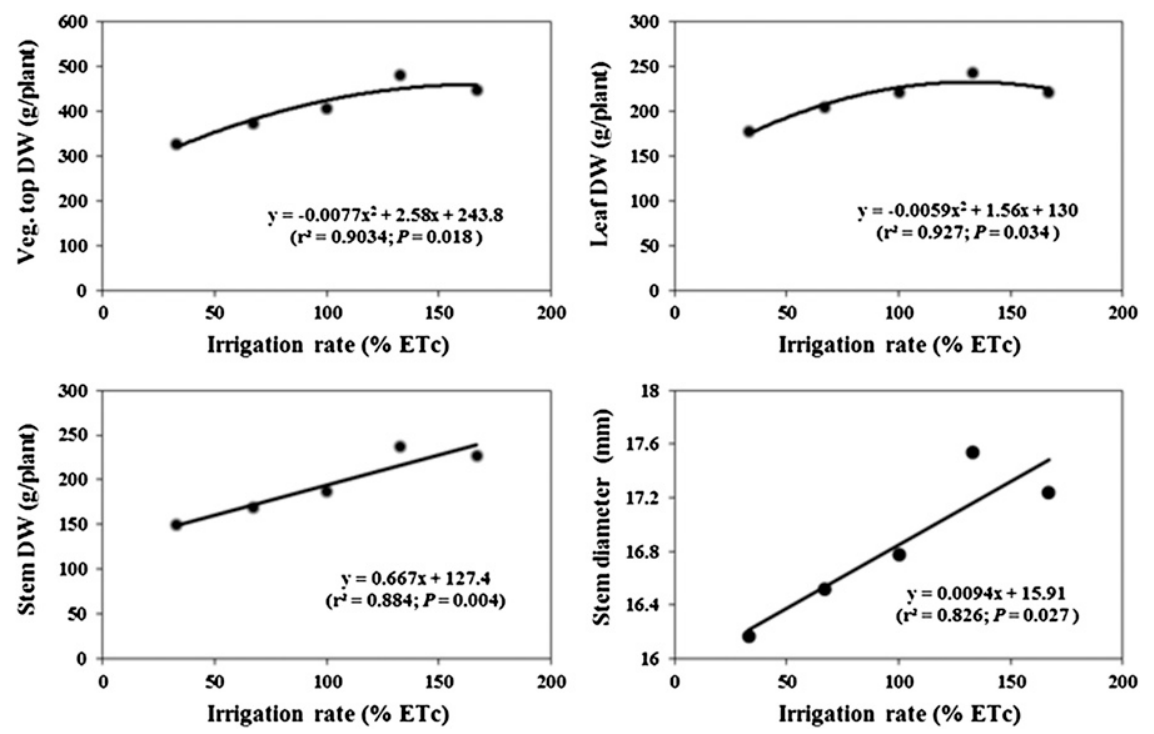

Fig. 1. Vegetative top dry weight (DW), leaf DW, stem DW, and stem diameter of mature eggplant plants as affected by irrigation rate. Irrigation rate was applied as percentage of crop evapotranspiration. Curve was fit by linear regression. Fall of 2010, Tifton, GA.

Table 1. Plant growth, leaf chlorophyll index (CI), and soil water content (SWC) as affected by irrigation rate in eggplant. Fall of 2011, Tifton, GA.

\begin{tabular}{lccccccc}
\hline Rate $(\%)^{\mathrm{z}}$ & $\begin{array}{c}\text { Seasonal stem } \\
\text { diam }(\mathrm{mm})\end{array}$ & $\begin{array}{c}\text { Mature stem } \\
\text { diam }(\mathrm{mm})\end{array}$ & $\begin{array}{c}\text { Seasonal } \\
\text { plant ht }(\mathrm{cm})\end{array}$ & $\begin{array}{c}\text { Mature plant } \\
\mathrm{ht}(\mathrm{cm})\end{array}$ & $\begin{array}{c}\text { Mature plant } \\
\mathrm{DW}(\mathrm{kg})\end{array}$ & $\begin{array}{c}\text { Seasonal } \\
\mathrm{CI}^{\mathrm{y}}\end{array}$ & $\begin{array}{c}\text { Seasonal } \\
\mathrm{SWC}^{\mathrm{x}}(\%)\end{array}$ \\
\hline 33 & 19.6 & 20.6 & 85.9 & 95.2 & 1.59 & 55.8 & 13.6 \\
67 & 20.4 & 21.4 & 89.6 & 99.8 & 1.73 & 55.2 & 13.7 \\
100 & 20.5 & 21.7 & 91.2 & 100.1 & 1.74 & 54.9 & 13.4 \\
133 & 20.2 & 21.1 & 90.6 & 99.2 & 1.73 & 54.0 & 13.2 \\
167 & 20.1 & 21.1 & 92.6 & 99.4 & 1.69 & 53.7 & 13.1 \\
Significance & & & & & & & \\
$\quad \mathrm{L}^{\mathrm{w}}$ & 0.019 & 0.647 & $<0.0001$ & 0.490 & 0.743 & 0.0008 & 0.353 \\
$\mathrm{Q}^{\mathrm{w}}$ & 0.032 & 0.298 & 0.043 & 0.287 & 0.314 & 0.967 & 0.728 \\
\hline
\end{tabular}

$\mathrm{DW}=$ dry weight.

zo $\%$ ETc = percentage of crop evapotranspiration

${ }^{y}$ Leaf CI measured with chlorophyll meter (SPAD-502; Minolta Co.).

${ }^{\mathrm{x}} \mathrm{SWC}$ in the $0-12 \mathrm{~cm}$ of soil profile measured manually with portable time-domain reflectometry sensor (CS-610; Campbell Sci.)

${ }^{\mathrm{w}} \mathrm{L}=$ linear; $\mathrm{Q}=$ quadratic response. 
Irrigation water use efficiency. Irrigation water use efficiency (IWUE) was calculated by dividing fruit weight $\left(\mathrm{kg} \cdot \mathrm{ha}^{-1}\right)$ by irrigation water received by the crop (in $\mathrm{mm}$ ) for each irrigation treatment.

Agronomic efficiency of nitrogen. Agronomic efficiency of nitrogen was calculated by dividing total eggplant fresh fruit weight $\left(\mathrm{kg} \cdot \mathrm{ha}^{-1}\right)$ by the amount of $\mathrm{N}\left(\mathrm{kg} \cdot \mathrm{ha}^{-1}\right)$ applied to the crop.

Fruit DW content and harvest index (HI). Five fruit per replicate were dried at $70{ }^{\circ} \mathrm{C}$ until constant weight ( $2-3 \mathrm{~d})$ and weighed to

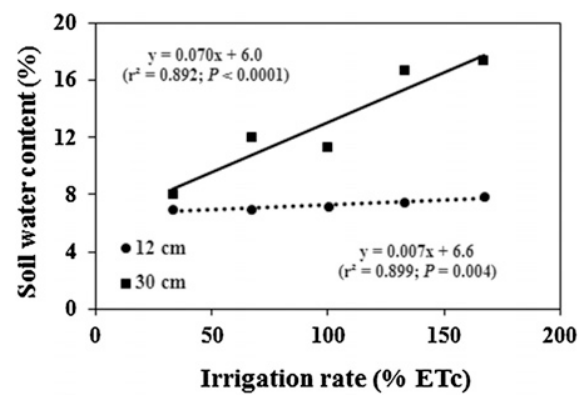

Fig. 2. Seasonal volumetric soil water content (measured at 12- and 30-cm depth) as influenced by irrigation rate. Irrigation rate was applied as percentage of crop evapotranspiration. Line was fit by linear regression. Fall of 2010, Tifton, GA. determine their DW. Fruit DW content was calculated as:

Fruit dry weight content

$=($ fruit dry weight $/$ fruit fresh weight $) \times 100$

Harvest index (HI) was calculated as:

Harvest index

$=($ total aerial dry weight $/$ fruit dry weight $)$ $\times 100$

Statistical analysis. Data were analyzed using the General Linear Model and Regression Procedures from SAS (SAS version 9.3, SAS Institute Inc., Cary, NC). Data means were separated by Fisher's protected least significant difference test at $95 \%$ confidence and response curves determined by orthogonal contrasts. Percentages were transformed to arcsin values before analysis. For clarity, nontransformed percentage means were used for presentation in tables and figures. Data from all years were pooled if no year $\times$ treatment interactions were found.

\section{Results and Discussion}

Weather. In 2010, average maximal, mean, and average minimum air temperature for the season were $28.8,22.6$, and $16.4{ }^{\circ} \mathrm{C}$, respectively. Cumulative ETo and rainfall for the season were 370 and $184 \mathrm{~mm}$, respectively. In 2011, average maximal, mean, and

Table 2. Leaf gas exchange and fluorescence as affected by irrigation rate and date in eggplant. Fall of 2010, Tifton, GA

\begin{tabular}{|c|c|c|c|c|c|}
\hline Date & Rate $(\%)^{\mathrm{z}}$ & $\begin{array}{l}\text { Net photosynthesis } \\
\quad\left(\mu \mathrm{mol} \cdot \mathrm{m}^{-2} \cdot \mathrm{s}^{-1}\right)^{\mathrm{y}}\end{array}$ & $g_{\mathrm{S}}\left(\mathrm{mol} \cdot \mathrm{m}^{-2} \cdot \mathrm{s}^{-1}\right)$ & WUE $\left(\mu \mathrm{mol} \cdot \mathrm{mmol}^{-1}\right)$ & $\begin{array}{l}\text { PS II efficiency } \\
\left(\mu \mathrm{mol} \cdot \mathrm{mmol}^{-1}\right)\end{array}$ \\
\hline \multirow[t]{8}{*}{6 Oct. $^{x}$} & 33 & 29.9 & 0.278 & 6.1 & 0.155 \\
\hline & 67 & 28.1 & 0.271 & 5.7 & 0.138 \\
\hline & 100 & 30.8 & 0.301 & 5.8 & 0.158 \\
\hline & 133 & 30.1 & 0.299 & 5.6 & 0.148 \\
\hline & 167 & 24.2 & 0.228 & 5.7 & 0.115 \\
\hline & Mean & 28.6 & 0.275 & 5.8 & 0.143 \\
\hline & $\mathrm{L}$ & 0.116 & 0.358 & 0.170 & 0.065 \\
\hline & $\mathrm{Q}$ & 0.068 & 0.155 & 0.236 & 0.068 \\
\hline \multirow[t]{8}{*}{20 Oct. } & 33 & 17.7 & 0.160 & 4.6 & 0.181 \\
\hline & 67 & 34.5 & 0.393 & 4.4 & 0.219 \\
\hline & 100 & 39.1 & 0.445 & 4.4 & 0.238 \\
\hline & 133 & 35.6 & 0.430 & 4.1 & 0.218 \\
\hline & 167 & 35.8 & 0.458 & 3.9 & 0.220 \\
\hline & Mean & 32.5 & 0.377 & 4.3 & 0.215 \\
\hline & $\mathrm{L}$ & $<0.0001$ & $<0.0001$ & 0.002 & 0.007 \\
\hline & $\mathrm{Q}$ & $<0.0001$ & $<0.0001$ & 0.010 & $<0.0001$ \\
\hline \multirow[t]{8}{*}{9 Nov. } & 33 & 18.6 & 0.172 & 4.02 & 0.176 \\
\hline & 67 & 24.2 & 0.240 & 3.82 & 0.181 \\
\hline & 100 & 25.1 & 0.251 & 4.0 & 0.188 \\
\hline & 133 & 25.2 & 0.251 & 4.0 & 0.180 \\
\hline & 167 & 23.6 & 0.251 & 3.9 & 0.180 \\
\hline & Mean & 23.3 & 0.233 & 3.9 & 0.181 \\
\hline & $\mathrm{L}^{\mathrm{w}}$ & 0.065 & 0.012 & 0.858 & 0.713 \\
\hline & $\mathrm{Q}^{\mathrm{w}}$ & 0.013 & 0.006 & 0.977 & 0.621 \\
\hline \multicolumn{6}{|l|}{ Significance } \\
\hline Date (D) & & $<0.0001$ & $<0.0001$ & $<0.0001$ & $<0.0001$ \\
\hline Rate (R) & & $<0.0001$ & $<0.0001$ & 0.025 & 0.005 \\
\hline $\mathrm{D} \times \mathrm{R}$ & & $<0.0001$ & $<0.0001$ & 0.540 & 0.002 \\
\hline
\end{tabular}

$g_{\mathrm{S}}=$ stomatal conductance; WUE = water use efficiency; PSII = photosystem II.

zo $\%$ ETc $=$ percentage of crop evapotranspiration.

${ }^{y}$ Leaf gas exchange and fluorescence measured with infrared gas analyzer (LI-COR 6400; LI-COR, Inc.).

${ }^{\mathrm{x}}$ Temperature and rainfall on days of measurement: 6 Oct. (maximum temperature $=23.9^{\circ} \mathrm{C}$; minimum temperature $=9^{\circ} \mathrm{C}$; rainfall $\left.=0 \mathrm{~mm}\right) ; 20$ Oct. $\left(\right.$ maximum temperature $=27.1^{\circ} \mathrm{C}$; minimum temperature $=14.6^{\circ} \mathrm{C}$; rainfall $=0 \mathrm{~mm}$ ); 9 Nov. $\left(\right.$ maximum temperature $=26.0^{\circ} \mathrm{C}$; minimum temperature $=6.1^{\circ} \mathrm{C}$; rainfall $=0 \mathrm{~mm}$ ). ${ }^{\mathrm{w}} \mathrm{L}=$ linear response; $\mathrm{Q}=$ quadratic response. average minimum air temperature were 28.6 , 22.5 , and $16.4{ }^{\circ} \mathrm{C}$, respectively. Cumulative ETo and rainfall for the season were 344 and $256 \mathrm{~mm}$, respectively.

Plant growth. In 2010, vegetative top DW, leaf DW, stem DW, and stem diameter increased with increasing irrigation rate (Fig. 1). Leaf weight ratio (LWR) [leaf biomass as a fraction of vegetative aboveground biomass $($ mean $=0.529)$ ] decreased with increasing irrigation rate $\left(r^{2}=0.92 ; P \leq\right.$ 0.05 ) from LWR of 0.543 at $33 \%$ ETc to LWR of 0.493 at $167 \%$ ETc, which indicates that plants allocated less biomass to leaves as irrigation rate increased. Bell pepper leaves have reduced leaf thickness at low light and low water stress conditions (Díaz-Pérez, 2013). In 2011, over the season, mean stem diameter was lowest at 33\% ETc $(P<0.05)$, although final stem diameter was unaffected by irrigation rate (Table 1). Mean seasonal plant height increased with irrigation rate, ranging from $66 \mathrm{~cm}(33 \%$ ETc) to $93 \mathrm{~cm}$ (167\% ETc); final plant height (4 Nov.) was unaffected by irrigation rate. Mature plant DW $($ mean $=1.70 \mathrm{~kg}$ ) was also unaffected by irrigation rate. Growth differences during midseason but not at the end of the season were probably because of high evaporative demand conditions that impacted plant growth at low irrigation rates during midseason. Late in the season, when evaporative demand was reduced, the effect of irrigation rate on plant growth was less detectable. The no treatment effect observed for eggplant in 2011 was likely because study was conducted in a low field that remained moist most of the time, nullifying the treatment effects.

Reduced eggplant plant growth at irrigation rates below 100\% ETo has been previously reported. Eggplant irrigated at $80 \%$ pan evaporation, every $8 \mathrm{~d}$, and $70 \%$ pan evaporation, every $12 \mathrm{~d}$, had reduction of $18 \%$ and $27 \%$ in plant height, and $13 \%$ and $21 \%$ in stem diameter, respectively (Kirnak et al., 2002). In bell pepper exposed to different soil water levels by varying drip emitter spacing, plant height and canopy diameter increased with decreasing emitter

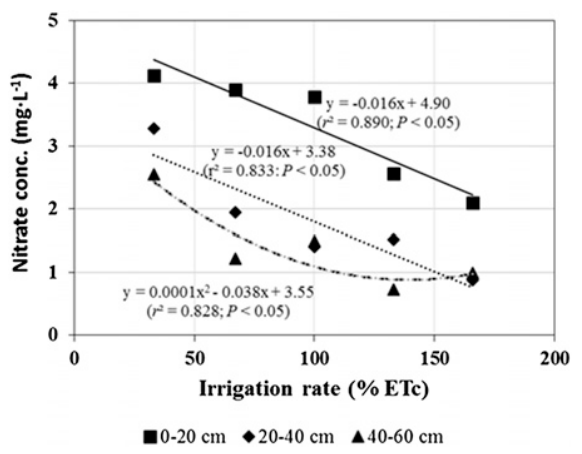

Fig. 3. Effect of irrigation rate and soil depth on the concentration of nitrate-nitrogen in the soil $(0$ to $60 \mathrm{~cm})$ in drip-irrigated eggplant grown on raised beds and plastic film mulch. Irrigation rate was applied as percentage of crop evapotranspiration. Line was fit by linear regression. Fall of 2010, Tifton, GA 
Table 3. Foliar mineral nutrient concentrations in eggplant as affected by several irrigation rates. Fall of 2010, Tifton, GA. ${ }^{\mathrm{z}}$

\begin{tabular}{|c|c|c|c|c|c|c|c|c|c|c|c|c|c|c|c|}
\hline \multirow[b]{2}{*}{ Rate $(\%)^{\mathrm{y}}$} & $\mathrm{N}$ & $\mathrm{P}$ & $\mathrm{K}$ & $\mathrm{Ca}$ & $\mathrm{Mg}$ & $\mathrm{S}$ & $\mathrm{Al}$ & B & $\mathrm{Cu}$ & $\mathrm{Fe}$ & $\mathrm{Mn}$ & Mo & $\mathrm{Na}$ & $\mathrm{Ni}$ & $\mathrm{Zn}$ \\
\hline & \multicolumn{6}{|c|}{$(\%)$} & \multicolumn{9}{|c|}{$\left(\mu g \cdot g^{-1}\right)$} \\
\hline 33 & 5.3 & 0.28 & 4.6 & 1.80 & 0.36 & 0.43 & 131 & 37 & 5 & 153 & 546 & 1.6 & 68 & 2.6 & 35 \\
\hline 67 & 5.1 & 0.31 & 4.3 & 1.77 & 0.34 & 0.38 & 108 & 38 & 6 & 137 & 480 & 2.0 & 72 & 2.3 & 33 \\
\hline 100 & 5.1 & 0.33 & 4.7 & 1.71 & 0.35 & 0.40 & 99 & 39 & 6 & 122 & 487 & 1.5 & 80 & 2.2 & 34 \\
\hline 133 & 5.0 & 0.32 & 4.2 & 1.82 & 0.34 & 0.36 & 114 & 42 & 6 & 136 & 478 & 2.7 & 78 & 2.9 & 32 \\
\hline 167 & 4.9 & 0.34 & 4.1 & 1.78 & 0.35 & 0.41 & 107 & 41 & 6 & 127 & 449 & 1.9 & 80 & 2.1 & 31 \\
\hline \multicolumn{16}{|c|}{ Significance } \\
\hline $\mathrm{L}^{\mathrm{x}}$ & 0.001 & 0.001 & 0.041 & 0.978 & 0.678 & 0.511 & 0.184 & 0.333 & 0.501 & 0.055 & 0.159 & 0.448 & 0.425 & 0.867 & 0.165 \\
\hline $\mathrm{Q}^{\mathrm{x}}$ & 0.007 & 0.005 & 0.079 & 0.958 & 0.865 & 0.406 & 0.139 & 0.634 & 0.722 & 0.067 & 0.359 & 0.685 & 0.704 & 0.956 & 0.384 \\
\hline
\end{tabular}

${ }^{\mathrm{z}}$ Leaf samples from mature plants (20 Oct. 2010).

y $\% \mathrm{ETc}=$ percentage of crop evapotranspiration.

${ }^{\mathrm{x}} \mathrm{L}=$ linear response; $\mathrm{Q}=$ quadratic response.
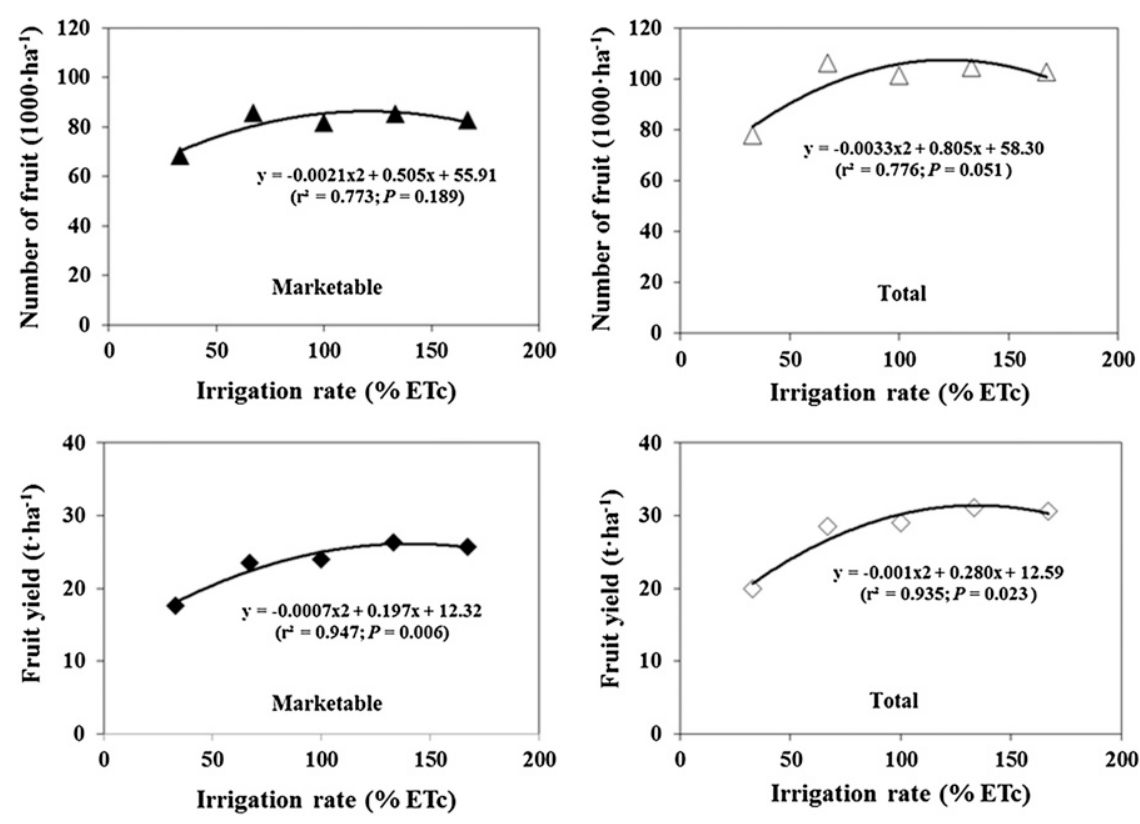

Fig. 4. Cumulative number of fruit and fruit yields as affected by irrigation rate in drip-irrigated eggplant grown on raised beds and plastic film mulch. Irrigation rate was applied as percentage of crop evapotranspiration. Line was fit by linear regression. Fall of 2010, Tifton, GA.

spacing (i.e., with increased soil water levels) (Madramootoo and Rigby, 1991).

Leaf CI. In 2010, CIs decreased with increased irrigation rate $(P=0.006)$, from 60.8 at $33 \%$ ETc to 59.0 at $167 \%$ ETc. In 2011, CI decreased from 55.8 at 33\% ETc to 53.7 at $167 \%$ ETc (Table 1). Decreased CI values with increased irrigation rates were likely due to dilution effect of nutrients, since plant growth was enhanced with increased irrigation rates. Decreased CI with increased irrigation rates may also be associated with increased nitrate leaching under high irrigation rates.

Soil water content. In 2010, the effect of irrigation rate on SWC varied with soil depth. At 0 - to $30-\mathrm{cm}$ depth, SWC increased with increasing irrigation rates (Fig. 2), whereas at 0 - to $12-\mathrm{cm}$ depth SWC was unaffected by irrigation rate. Differences in soil moisture in the different soil depths indicate a higher soil water uptake by plants, because of greater presence of roots at $0-12 \mathrm{~cm}$ than at $0-$ to 30-cm depth; they also indicate that high rates of irrigation $(>100 \% \mathrm{ETc})$ result in wasted water because much water at 0 - to $30-\mathrm{cm}$ depth was not taken up by the crop; and they suggest that soil moisture measurement at 0 - to $30-\mathrm{cm}$ depth was more sensitive to detect changes in soil moisture than measurement at 0 - to $12-\mathrm{cm}$ depth.

As in 2010, seasonal SWC at $0-$ to $12-\mathrm{cm}$ depth was also similar among irrigation rates (mean $=13.4 \%)$ in 2011. In addition to the high presence of roots at 0 - to $12-\mathrm{cm}$ depth, SWC values were similar among treatments in 2011 probably because the study was conducted in a low field, with a nearly level slope, where soil was commonly moist throughout the season, likely due to lateral water movement from upper sections of the field. There was an impermeable clay layer 30 - to $40-\mathrm{cm}$ deep in the soil profile that probably allowed water to flow from upper to lower areas within the farm.

Leaf gas exchange. In 2010, the effect of irrigation rate on leaf gas exchange varied by date (Table 2). Net photosynthesis, $g_{\mathrm{S}}$, and photosynthetic WUE were unaffected by irrigation rate on 6 Oct. 2010. Lack of treatment differences on 6 Oct. was probably attributable to relatively low temperatures on day of measurement (mean temperature = $16.4{ }^{\circ} \mathrm{C}$ ), resulting in low crop evaporative demand and low crop water stress. Net photosynthesis and $g_{\mathrm{S}}$ were lowest at $33 \%$ ETc on 20 Oct. and 9 Nov. Water use efficiency was highest and PSII efficiency was lowest at $33 \%$ ETc on 20 Oct. The fact that gas exchange variables were not reduced at $67 \%$ ETc compared with higher irrigation rates suggests that plants at $67 \%$ ETc were likely unaffected by water stress. However, since gas exchange measurements were conducted only in mature plants, late in the season, when evaporative demand was reduced, it is possible that earlier in the season plants may have had experienced increased water stress at reduced irrigation rates, as suggested by the reduced plant growth at reduced irrigation rates. In 2011 , leaf net photosynthesis $\left(\right.$ mean $\left.=28.3 \mu \mathrm{mol} \cdot \mathrm{m}^{-2} \cdot \mathrm{s}^{-1}\right), g_{\mathrm{S}}($ mean $=$ $\left.0.248 \mathrm{~mol} \cdot \mathrm{m}^{-2} \cdot \mathrm{s}^{-1}\right)$, WUE $($ mean $=4.24$ $\mu \mathrm{mol} \cdot \mathrm{mmol}^{-1}$ ), and PSII (mean $=0.189$ $\mu \mathrm{mol} \cdot \mathrm{mmol}^{-1}$ ) were unaffected by irrigation rate. Air maximal and minimal temperature on the day of measurement were 27.5 and $11.0^{\circ} \mathrm{C}$, respectively. Lack of differences in gas exchange are consistent with the lack of differences in plant growth among irrigation rates observed in 2011.

Irrigation at $33 \%$ ETc was probably insufficient to satisfy eggplant water requirements, as suggested by the reduced leaf gas exchange values (Table 2). Reduced irrigation rates can result in decreased gas exchange in solanaceous crops. Transpiration, leaf $g_{S}$, and leaf net photosynthesis in eggplant were reduced with water stress and effects varied depending on stress severity and duration (Sarker et al., 2005). In habanero pepper (Capsicum chinense Jacq.), there was reduced $g_{S}$ and net photosynthesis with increased time between irrigations (Jaimez et al., 1999).

Soil nitrate. Soil nitrate concentration decreased with increasing irrigation rate $(P=0.002)$ and soil depth $(P=0.003)$, indicating that nitrate leaching to the deepest parts of the soil was enhanced with increased irrigation rates (Fig. 3). Decreased soil nitrate concentration may also be due to high $\mathrm{N}$ uptake by the crop, as suggested by augmented vegetative growth with increasing irrigation rate. Nitrate present at 40-60 depth is usually lost as it is not recovered by plants' roots. Decreased nitrate in $40-$ to $60-\mathrm{cm}$ zone is thus solely due to leaching. 
Foliar mineral nutrient concentrations and CI. In 2010, foliar $\mathrm{N}$ and $\mathrm{K}$ concentrations decreased and $\mathrm{P}$ increased with increasing irrigation rate (Table 3 ). Other foliar nutrients concentrations were unaffected by irrigation rate. Nitrogen, K, and CI decreased with irrigation rate, possibly as a result of a dilution effect associated with increased aboveground plant growth. In addition, at high irrigation rates plants likely had reduced access to soil $\mathrm{N}$ due to increased nitrate leaching. Plant water stress in eggplant can reduce foliar $\mathrm{N}, \mathrm{P}$, and $\mathrm{K}$ concentrations compared with well-irrigated plants (Kirnak et al., 2002). In the present study, however,

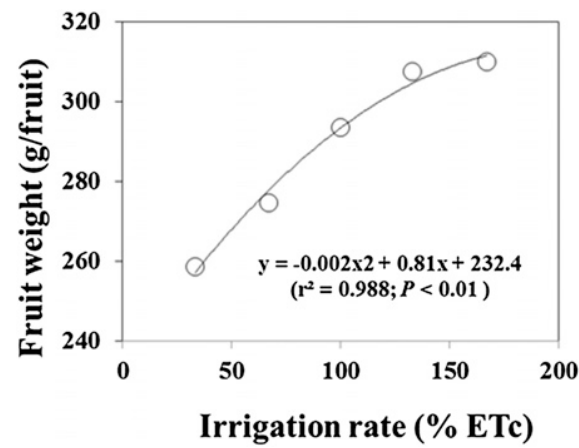

Fig. 5. Individual fruit weight as influenced by irrigation rate in drip-irrigated eggplant grown on raised beds and plastic film mulch. Irrigation rate was applied as percentage of crop evapotranspiration. Line was fit by linear regression. Fall of 2010, Tifton, GA.

Table 4. Fruit yield of eggplant as affected by irrigation rate. Fall of 2011, Tifton, GA.

\begin{tabular}{|c|c|c|c|c|c|c|c|}
\hline \multirow[b]{2}{*}{ Rate $(\%)^{z}$} & \multicolumn{2}{|c|}{ Marketable } & \multicolumn{2}{|c|}{ Cull } & \multicolumn{2}{|c|}{ Total } & \multirow{2}{*}{$\begin{array}{l}\text { Fruit wt } \\
\text { (g/fruit) }\end{array}$} \\
\hline & $(1000 /$ ha $)$ & $\overline{\left(t \cdot h a^{-1}\right)}$ & $(1000 / \mathrm{ha})$ & $\overline{\left(\mathrm{t} \cdot \mathrm{ha}^{-1}\right)}$ & $(1000 /$ ha $)$ & $\overline{\left(t \cdot h a^{-1}\right)}$ & \\
\hline 33 & 164 & 36 & 8.4 & 1.6 & 191 & 37 & 197 \\
\hline 67 & 169 & 37 & 4.2 & 0.8 & 191 & 38 & 198 \\
\hline 100 & 154 & 35 & 7.9 & 1.6 & 178 & 36 & 203 \\
\hline 133 & 180 & 41 & 5.5 & 1.2 & 205 & 42 & 206 \\
\hline 167 & 179 & 40 & 8.4 & 1.3 & 207 & 41 & 199 \\
\hline \multicolumn{8}{|c|}{ Significance } \\
\hline $\mathrm{L}^{\mathrm{y}}$ & 0.206 & 0.140 & 0.778 & 0.918 & 0.208 & 0.145 & 0.502 \\
\hline $\mathrm{Q}^{\mathrm{y}}$ & 0.341 & 0.324 & 0.247 & 0.747 & 0.297 & 0.322 & 0.503 \\
\hline
\end{tabular}

zo ETc $=$ percentage of crop evapotranspiration.

${ }^{\mathrm{y}} \mathrm{L}=$ linear; $\mathrm{Q}=$ quadratic response.

Table 5. Irrigation, cumulative rainfall, IWUE, and AEN of eggplant crop grown on plastic film mulch Fall of 2010 and 2011, Tifton, GA.

\begin{tabular}{|c|c|c|c|c|c|c|c|c|c|c|}
\hline \multirow[b]{2}{*}{ Rate $(\%)^{z}$} & \multicolumn{2}{|c|}{$\begin{array}{l}\text { Irrigation } \\
(\mathrm{mm})\end{array}$} & \multicolumn{2}{|c|}{$\begin{array}{l}\text { Rainfall } \\
(\mathrm{mm})\end{array}$} & \multicolumn{2}{|c|}{$\begin{array}{l}\text { Total water } \\
(\mathrm{mm})\end{array}$} & \multicolumn{2}{|c|}{$\begin{array}{c}\text { IWUE }^{\mathrm{y}} \\
\left(\mathrm{kg} \cdot \mathrm{ha}^{-1} \cdot \mathrm{mm}^{-1}\right)\end{array}$} & \multicolumn{2}{|c|}{$\begin{array}{c}\mathrm{AEN}^{\mathrm{x}} \\
\left(\mathrm{kg} \cdot \mathrm{kg}^{-1} \mathrm{~N}\right)\end{array}$} \\
\hline & 2010 & 2011 & 2010 & 2011 & 2010 & 2011 & 2010 & 2011 & 2010 & 2011 \\
\hline 33 & 149 & 83 & 217 & 318 & 366 & 401 & 134 & 449 & 92 & 172 \\
\hline 67 & 211 & 118 & 217 & 318 & 428 & 436 & 135 & 321 & 131 & 178 \\
\hline 100 & 272 & 152 & 217 & 318 & 489 & 470 & 107 & 238 & 133 & 166 \\
\hline 133 & 333 & 187 & 217 & 318 & 550 & 505 & 93 & 225 & 143 & 193 \\
\hline 167 & 394 & 221 & 217 & 318 & 611 & 539 & 78 & 184 & 141 & 187 \\
\hline \multicolumn{11}{|c|}{ Significance } \\
\hline $\mathrm{L}^{\mathrm{w}}$ & & & & & & & $<0.0001$ & $<0.0001$ & 0.006 & 0.146 \\
\hline $\mathrm{Q}^{\mathrm{w}}$ & & & & & & & 0.0002 & $<0.0001$ & 0.006 & 0.324 \\
\hline
\end{tabular}

zo ETc $=$ percentage of crop evapotranspiration.

${ }^{y}$ IWUE $=$ irrigation water use efficiency (IWUE $=$ fruit wt/irrigation water); fruit wt $=$ total fruit fresh weight $\left(\mathrm{kg} \cdot \mathrm{ha}^{-1}\right)$; irrigation water $(\mathrm{mm})$.

${ }^{\mathrm{x}} \mathrm{AEN}=$ agronomic efficiency of nitrogen $(\mathrm{AEN}=$ fruit wt $/$ total $\mathrm{N}) ;$ total fruit fresh weight $\left(\mathrm{kg} \cdot \mathrm{ha}^{-1}\right) ;$ total $^{\mathrm{N}}$ applied $\left(\mathrm{kg} \cdot \mathrm{ha}^{-1}\right)$.

${ }^{\mathrm{w}} \mathrm{L}=$ linear; $\mathrm{Q}=$ quadratic response.
2002). In 2011, irrigation rate had no effect on the number or yields of marketable, cull, and total fruit, or on individual fruit weight (Table 4). There were no significant interactions between harvest dates and irrigation rates. There was also a higher correlation between fruit number and fruit yield $\left(R^{2}=\right.$ $0.92 ; P<0.0001)$ than between individual fruit weight and fruit yield $\left(R^{2}=0.185 ; P=\right.$ $0.001)$. Results suggest that eggplant may tolerate moderate water stress, since plants irrigated at $67 \%$ ETc produced fruit yields similar to those of plants irrigated at $100 \%$ ETc or higher rates. Thus, there is a potential to reduce irrigation rates below $100 \%$ ETc without negatively impacting fruit yields.

Irrigation water use efficiency and agronomic efficiency of nitrogen. Plants received more irrigation water in 2010 than in 2011 as a result of reduced rainfall in 2010 (Table 5). In both years, IWUE decreased with increasing irrigation rate. IWUE was greatly reduced and there were significant effects of irrigation rates on several variables in 2010, but not in 2011. Increased IWUE and increased SWC in 2011 (mean $=13.4 \%$ at 0 to $12-\mathrm{cm}$ depth) relative to SWC in 2010 (mean $=7.5 \%$ at 0 - to $12-\mathrm{cm}$ depth) are probably associated with increased contribution of soil water from rainfall and drainage water from upper areas of the field; in 2011, field used was low and nearly flat.

Although there were differences in leaf $\mathrm{N}$ among irrigation treatments, fruit yield was likely more related to irrigation rate than to leaf $N$. Total yield showed a quadratic relationship with leaf $\mathrm{N}\left(R^{2}=0.185 ; P=0.013\right)$; total yield was unaffected by leaf $\mathrm{N}$ below $5.1 \%$ and was lowest at the highest leaf $\mathrm{N}$ $(5.3 \%)$ occurred at the lowest irrigation rate (33\% ETc).

Agronomic efficiency of $\mathrm{N}$ increased with irrigation rate in 2010 likely as a result of increased fruit yield associated with improved plant water status; AEN was unaffected by irrigation rate in 2011. AEN values in this study (range 92 to $187 \mathrm{~kg} \cdot \mathrm{kg}^{-1} \mathrm{~N}$ ) were lower compared with values of other studies on eggplant $\left(\right.$ range $=324$ to $859 \mathrm{~kg} \cdot \mathrm{kg}^{-1} \mathrm{~N}$ ) (Aujla et al., 2007), probably because the harvest period in this study was reduced. Low AEN values may also mean that eggplant crop in this study made inefficient use of $\mathrm{N}$ fertilizer, probably in part due to overfertilization. Aujla et al. (2007) reported that irrigation rate and $\mathrm{N}$ fertilization rate interacted in drip-irrigated eggplants; they also found that irrigation at $75 \%$ pan evaporation and $120 \mathrm{~kg} \cdot \mathrm{ha}^{-1} \mathrm{~N}$ produced the greatest yields, and that AEN increased with increased $\mathrm{N}$ fertilization rate.

Fruit DW content and HI. In year 2010 , fruit DW content (mean $=6.2 \%$ ) was unaffected by irrigation rate. In a study under semiarid conditions, soluble DW or soluble solids in eggplant decreased with increased irrigation rates (Kirnak et al., 2002). In greenhouse-grown eggplant, increased irrigation rates also decreased fruit DW content (Chartzoulakis and Drosos, 1995). 
Harvest index was unaffected by irrigation rate (mean $\mathrm{HI}=0.32$ ). These data suggest that eggplant is more tolerant to drought than other solanaceous crops (Behboudian, 1977). Our measurements of HI did not include root biomass. However, under water stress, eggplants possibly allocated increased amounts of assimilates for root growth as occurs in other plants (Larcher, 1995). In habanero pepper, an irrigation rate of $20 \%$ of available water produced reduced values of HI (Quintal Ortiz et al., 2012). In tomato, there was no difference in total dry biomass and HI between the control and a partial irrigation treatment, but total dry biomass and HI significantly decreased under regulated deficit irrigation (Lei et al., 2009); moderate water stress-induced osmotic regulation under partial root drying conditions, leading to normal water status and the same level of biomass. Eggplant in our study was also able to maintain high fruit yields at moderate levels of water stress, suggesting that, as tomato, eggplant is also able to develop mechanisms to deal with water stress such as osmoregulation.

In conclusion, the results from this research indicate that eggplant may tolerate moderate water stress, since plants irrigated at $67 \%$ ETc had no detrimental effects on plant growth and leaf gas exchange and produced fruit yields similar to those of plants irrigated at $100 \%$ ETc. Thus, there is a potential to reduce current irrigation rates without negatively impacting fruit yields or quality.

\section{Literature Cited}

Allen, R.G., L.S. Pereira, D. Raes, and M. Smith. 1998. Crop evapotranspiration: Guidelines for computing crop water requirements. Food and Agriculture Organization of the United Nations, Rome.

Aujla, M.S., H.S. Thind, and G.S. Buttar. 2007. Fruit yield and water use efficiency of eggplant (Solanum melongema L.) as influenced by different quantities of nitrogen and water applied through drip and furrow irrigation. Sci. Hort. 112:142-148.
Behboudian, M.H. 1977. Responses of eggplant to drought. I. Plant water balance. Sci. Hort. 7:303310.

CAED. 2013. 2012 Georgia farm gate value report. CAES, Univ. of Georgia, Athens, GA.

Calhoun, J.W. 1983. Soil survey of Tift County, Georgia. United States Department of Agriculture, Soil Conservation Service, University of Georgia, GA.

Chartzoulakis, K. and N. Drosos. 1995. Water use and yield of greenhouse grown eggplant under drip irrigation. Agr. Water Mgt. 28:113-120.

Díaz-Pérez, J.C. 2013. Bell pepper (Capsicum annum L.) crop as affected by shade level: Microenvironment, plant growth, leaf gas exchange, and leaf mineral nutrient concentration. HortScience 48:175-182.

Díaz-Pérez, J.C., D. Granberry, K. Seebold, D. Giddings, and D. Bertrand. 2004. Irrigation levels affect plant growth and fruit yield of drip-irrigated bell pepper. HortScience 39: 748.

Gaveh, E.A., G.M. Timpo, S.K. Agodzo, and D.H. Shin. 2011. Effect of Irrigation, transplant age and season on growth, yield and irrigation water use efficiency of the African eggplant. J. Hort. Environ. Biotechnol. 52:13-28.

Jaimez, R.E., F. Rada, and C. Garcia-Nunez. 1999. The effect of irrigation frequency on water and carbon relations in three cultivars of sweet pepper (Capsicum chinense Jacq), in a tropical semiarid region. Sci. Hort. 81:301-308.

Karam, F., R. Saliba, S. Skaf, J. Breidy, Y. Rouphael, and J. Balendonck. 2011. Yield and water use of eggplants (Solanum melongena L.) under full and deficit irrigation regimes. Agr. Water Mgt. 98:1307-1316.

Kirnak, H., I. Tas, C. Kaya, and D. Higgs. 2002. Effects of deficit irrigation on growth, yield, and fruit quality of eggplant under semi-arid conditions. Austral. J. Agr. Res. 53:1367-1373.

Larcher, W. 1995. Physiological plant ecology: Ecophysiological and stress physiology of functional groups. Springer, Berlin, Germany.

Lei, S., Q. Yunzhou, J. Fengchao, S. Changhai, Y. Chao, L. Yuxin, L. Mengyu, and D. Baodi. 2009. Physiological mechanism contributing to efficient use of water in field tomato under different irrigation. Plant Soil Environ. 55: 128-133.
Liu, Y.J., Y.P. Tong, Y.G. Zhu, H. Ding, and E.A. Smith. 2006. Leaf chlorophyll readings as an indicator for spinach yield and nutritional quality with different nitrogen fertilizer applications. J. Plant Nutr. 29:1207-1217.

Locascio, S.J., S.M. Olson, and F.M. Rhoads. 1989. Water quantity and time of $\mathrm{N}$ and $\mathrm{K}$ application for trickle-irrigated tomatoes. J. Amer. Soc. Hort. Sci. 114:265-268.

Madramootoo, C.A. and M. Rigby. 1991. Effects of trickle irrigation on the growth and sunscald of bell peppers (Capsicum annuиm L.) in southern Quebec. Agr. Water Mgt. 19:181-189.

Ngouajio, M., G.Y. Wang, and R. Goldy. 2007. Withholding of drip irrigation between transplanting and flowering increases the yield of field-grown tomato under plastic mulch. Agr. Water Mgt. 87:285-291.

Ozores-Hampton, M. 2014. Conventional and specialty eggplant varieties in Florida. Horticultural Sciences Department, Univ. of Florida/ Institute of Food and Agricultural Sciences. Document HS1243. 12 June 2015. <http://edis. ifas.ufl.edu/hs1243>.

Pereira, L.S., R.G. Allen, M. Smith, and D. Raes. 2015. Crop evapotranspiration estimation with FAO56: Past and future. Agr. Water Mgt. 147: 4-20.

Quintal Ortiz, W.C., A. Perez-Gutierrez, L. Latournerie Moreno, C. May-Lara, E. Ruiz Sanchez, and A.J. Martinez Chacon. 2012. Water use, water potential, and yield of habanero pepper (Capsicum chinense Jacq.). Rev. Fitotec. Mex. 35:155-160.

Sarker, B.C., M. Hara, and M. Uemura. 2005. Proline synthesis, physiological responses and biomass yield of eggplants during and after repetitive soil moisture stress. Sci. Hort. 103: 387-402.

Sezen, S.M., A. Yazar, and S. Eker. 2006. Effect of drip irrigation regimes on yield and quality of field grown bell pepper. Agr. Water Mgt. 81:115-131.

Simonne, E.H., M.D. Dukes, R.C. Hochmuth, D.W. Studstill, G. Avezou, and D. Jarry. 2006. Scheduling drip irrigation for bell pepper grown with plasticulture. J. Plant Nutr. 29: 1729-1739.

USDA. 2013. United States standards for grades of eggplant. United States Department of Agriculture. 